\title{
Service-Learning as a Pedagogy to Promote the Content, Cross-Cultural, and Language-Learning of ESL Students
}

\section{Linda Heuser}

This article describes the incorporation of service-learning in a sheltered-content course called American Society for Japanese college sophomores studying in the United States. By engaging students in activities designed to address community needs, service-learning holds great promise for furthering cognitive knowledge, cross-cultural awareness, and language competences. After profiling the academic program, a definition of service-learning is provided along with a review of the preparatory steps leading to a weekend of service. The exercises developed to help students make sense of their firsthand experiences and a critique of this instructional activity round out this discussion.

Service-learning has exciting pedagogical potential for content, cross-cultural, and language development of international ESL students. Typically, this educational approach has involved non-native English-speaking students performing service when they study abroad (e.g., volunteering in schools, health clinics, and social service programs). Less frequently has it included international ESL students enrolled in institutions of higher education in the United States and Canada. This article reports, from the faculty perspective, on the use of service-learning as a "capstone experience" in a sheltered-content sociology course called American Society for Japanese college sophomores studying in a 10-month academic program in Salem, Oregon. Participating in a weekend of service activities at a youth drop-in center, homeless shelter, women's crisis center, and residential facility for mentally ill homeless adults, students had an opportunity to increase their cognitive knowledge about poverty and homelessness, heighten their crosscultural understanding, and practice their English in a real-life setting. I begin with a brief program profile followed by a description of service-learning and its incorporation into the American Society content course and its paired Applied English language course.

\section{Program Profile}

The students enrolled in the American Society course were part of a 10month credit-bearing academic program at Tokyo International University of America (TIUA). Created in 1989 through a partnership between Tokyo 
International University (TIU) in Kawagoe, Japan and Willamette University in Salem, Oregon, this institution, which promotes global education and cross-cultural exchange, serves approximately 100 Japanese sophomores annually. Functioning as an academically distinct program, all courses are designed exclusively for TIUA students. Nonetheless, students have the option to take Willamette University courses and to live with American roommates. Thus TIUA and Willamette University share facilities, student activities, and academic affairs.

The TIUA educational program is divided into three distinct sessions. Beginning in February with a 12-week spring semester, TIUA English faculty focus on language and cultural skills instruction. This training prepares students for the six-week intensive summer session and 15-week fall semester, during which they take elective content offerings paired with Applied English courses. The elective courses, taught by Willamette University professors, introduce students to the content of different disciplines such as sociology, economics, and history. The accompanying Applied English courses, staffed by TIUA faculty, then use the content for language, cultural, and study skills development. Generally taking two electives and two linked Applied English courses in the summer and fall sessions, students earn sufficient credits to return to TIU in Japan as juniors.

In addition to course work, students at TIUA are expected to participate in three community service projects in which they volunteer during their stay in the US. The fulfillment of this requirement can be achieved in a number of ways, from individual one-time projects to group weekend or weeklong activities. In most instances, the volunteering takes place without the benefits of formal or structured learning (Kraft, 1996). Consequently, TIUA students can find themselves engaging in community service without knowing what their experiences mean.

Service-learning can provide the missing educational connection for these ESL students. By stressing the integration of experience with the academic curriculum, it helps students to make sense of the community service in which they have been involved. A description of our current efforts demands a grounded definition of service-learning.

\section{Service-Learning}

A review of the literature reveals the widespread proliferation of terms and definitions. In fact, Kendall (1990) encountered over 147 such terms (e.g., citizen involvement, community-based education, cross-cultural learning, education for social responsibility, public service, voluntary action), and Jacoby (1996), in a more recent article, contends that even more are in use today. Given the lack of agreement among educators in this field, I have chosen to characterize service-learning as "a form of experiential education in which students engage in activities that address human and community 
needs together with structured opportunities designed to promote student learning and development" (Jacoby, 1996, p. 5). As such, service-learning is the integration of community service with academic course work (Chapin, 1998).

This definition has a number of key components. First, it highlights the importance of learning-by-participation. What is studied in the classroom is made more meaningful because students engaging in real-life experiences face situations that may challenge them to examine more closely previous assumptions (Ciaccio \& Walker, 1998). In addition, service-learning brings students and community members together in a mutually educational relationship. Otherwise known as reciprocity, this idea supposes that all parties are learners and teachers in the context of service activities (Jacoby, 1996; Kendall, 1991; Mintz \& Hesser, 1996).

Because service does not automatically result in learning (Ciaccio \& Walker, 1998), service-learning must provide a way for students to make sense of their experiences through opportunities intentionally designed to foster critical thinking (Beckman, 1997). Also labeled reflection, this feature distinguishes service-learning from charity or any action that is performed without awareness of the underlying causes contributing to the original problem (Parker-Gwin \& Mabry, 1998). Through reflection, students move from the concrete to the abstract (Hatcher \& Bringle, 1997) as they link their firsthand experiences with course content, thereby increasing their understanding of the historical, sociological, cultural, and political contexts behind the needs they seek to address (Jacoby, 1996; Jeavons, 1989; Kendall, 1991). At its best, service-learning is an integrative process that involves participation in the community, critical reflection on that participation, and the connection of experiences to class-based knowledge (Dollar \& Rust, 1983).

Admittedly, service-learning activities vary in the extent to which they promote content knowledge, cross-cultural awareness, and language proficiency. For example, students placed in a setting where they are not in direct contact with community members may have different educational experiences than their peers who are engaged in face-to-face interactions (Delve, Mintz, \& Stewart, 1990). Moreover, the frequency and duration of servicelearning may have an impact on their development, because students who visit a service site on a weekly basis come away with more in-depth experiences than classmates participating in a one-time service activity.

As Delve et al. (1990) spell out in their Service Learning Model, exploration is the usual starting point for someone who has not had much exposure to service. In this first phase, students join in one-time, short-term group activities that may or may not bring them into contact with other people. Because students in our paired content and language courses have had minimal involvement with community service and little or no knowledge of service-learning, an exploratory phase project seems a logical place to begin. 


\section{Course Rationale for the Use of Service-Learning}

The idea of combining ESL and service-learning is relatively new. Given the paucity of literature in this area, I turned to publications on international service-learning to justify the adoption of this pedagogical technique in a sheltered-content course. In my estimation, Weaver, Kauffmann, and Martin (1989) advance the most convincing argument. According to them, servicelearning, most notably in the international arena, has four principal characteristics: cognitive knowledge, cross-cultural understanding, language competence, and personal maturity.

Guided by the first three principles only, I (a sociologist) and the Applied English professor chose to use what we are calling ESL service-learning because of its potential to increase and reinforce cognitive knowledge by acquainting students with other people and societies through firsthand experiences (Brandell, Hitch, Kromer, \& Misner, 1994; Crabtree, 1998; Kelleher \& O'Brien, 1991; Ochoa, 1996; Thullen, 1989). Service-learning offers an occasion to understand how others view the world through exposure to different cultural settings (Burkholder, 1989; Crabtree, 1998; Eberly, 1997; Hayes, 1996; Kwapong, 1989; Rasmussen, 1991; Ward, 1997). In addition, service learning bolsters language skills as students read, write, speak, and listen in an authentic context (Beebe \& DeCosta, 1993; Rasmussen, 1991; Yoder, Retish, \& Wade, 1996). As a result, ESL service-learning shows promise in furthering students' content knowledge, cross-cultural awareness, and language competences.

\section{Background of the Course}

American Society is a college-level sheltered-content course taught for the past six years to TIUA students who have an average TOEFL score of 446. Enrolling 14-22 students annually, this course, scheduled for 60 minutes on Mondays, Wednesdays, and Fridays, has been designed as a sociological investigation of contemporary social issues. The course is divided into four units, and students are first introduced to the field of sociology through the study of values, norms, stereotypes, ethnocentrism, cultural relativity, and culture shock. Afterward, they learn about poverty and homelessness, volunteerism, and a topic of their choice such as AIDS, crime and guns, or recycling.

In the linked Applied English course, students meet for 90 minutes on Tuesdays and Thursdays to practice reading, writing, speaking, and listening in English by drawing on the content from American Society. As we are opposed to an artificial separation between courses, we (the sociologist and the Applied English professor) seek to include language in content classes and content in language classes (Crandall, Spanos, Christian, SimichDudgeon \& Willetts, 1987; de la Luz Reyes \& Molner, 1991). Believing that 
content provides a motivational incentive for language-learning and that language becomes the vehicle by which to access content (Snow, Met, \& Genesee, 1989), we work diligently to coordinate our curricula. In addition, the Applied English professor attends and participates in the activities of the content course as is expected of all TIUA faculty.

Our approach to teaching content and language applies some of the ideas advocated by proponents of critical pedagogy. First, we consider students to be active participants in a communal classroom where we question, discuss, and debate together the topics under investigation (Giroux, 1993; hooks, 1994; Leistyna, 1999). Students are not told what to think or believe as in a transmittal model of education (King, 1993), but are provided with opportunities to develop literacy and understanding through what Shor (1992) calls a reading-and-writing-to-learn approach. Second, we try to promote a problem-posing dialogue whereby we begin our study of a particular social issue with questions that allow students rather than the teachers to voice their thoughts and opinions (Friere, 1970; Giroux, 1993; Morgan, 1998; Shor, 1992, 1996). Third, we maintain that students must understand the larger social, historical, economic, and political conditions out of which problems such as homelessness or racism arise (Giroux, 1997; Leistyna, 1999). Fourth, we contend that by merging language instruction, academic content, and daily experiences (Morgan, 1998; Shor, 1992) —or the analytical and experiential (hooks, 1994)-learning becomes more meaningful and relevant.

Accordingly, we welcome student input in the development of our curriculum. In the early years of these courses, we had majors in international relations, international economics, social welfare, and psychology who were keenly interested in knowing more about the volunteering (a term often used interchangeably with community service). They had noticed the active involvement of American college students in such activities and wanted to know the reason for this involvement. Although some actively sought to satisfy their curiosity by volunteering, writing seminar papers on this topic, and talking with their American roommates, they still desired further information. As a result, we added a unit on volunteerism and a service-learning project in the hope that such a learning-by-participating approach would answer many of their questions.

\section{Preparation for Service-Learning}

Any service-learning project has four key elements: preparation, action, reflection, and evaluation (Rice, 1996). For learning to occur through service or action, it must start with preparation and end with reflection, both of which provide the contextual grounding for making sense of students' experiences. Evaluation then provides the critical input to strengthen the first three elements. Our preparation in American Society and the Applied English courses centers. on the academic study of poverty, homelessness, and 
volunteerism. The following description of the content and language activities in these two units shows how we prepare students for service.

\section{Unit on Poverty and Homelessness}

Committed to involving students actively in a problem-posing dialogue that draws on language, academic content, and daily experiences, we began this unit with a reading, writing, speaking, and listening exercise (Table 1). After reading an article about poverty assigned by the sociologist, students replied in writing to a series of study guide questions developed by the Applied English professor to assess their comprehension of key sociological terms. Referring to their written responses and their personal experiences with poverty in Japan and the US, students orally answered questions posed by the sociologist and listened to her as she defined social inequality, social stratification, absolute poverty, and relative poverty. These ideas were reviewed in the Applied English course as students discussed what they had learned.

The study of the demographics and the causes of poverty followed a similar format. In addition, students watched a video, Living on the Edge (Gasciato \& Hughes, 1995), that showed the impact of poverty on several families whose members had lost their jobs during a downturn in the US economy. After listening to their stories, students completed oral and written exercises in which they analyzed the social factors that affected these families' situations.

Turning our attention to homelessness, students activated prior knowledge by describing its meaning orally before the sociologist defined it. A lecture about who is homeless and why homelessness exists in the US came next, along with an open-notebook quiz on content prepared by the Applied English professor to make sure that students were listening and accurately recording the lecture in notetaking. To help students more fully grasp the realities of homelessness, we viewed and discussed a video entitled Streetwise (McCall \& Ball, 1987) about youth who live on the streets in Seattle, Washington.

Because most students have seen but not experienced poverty and homelessness, we involved them in a number of role-plays and simulations. First, they participated in a game called Starpower (Shirts, 1969) where they used their speaking and listening skills to bargain in English with one another for colored tokens assigned different values as they tried to accrue enough points to be placed in the middle or upper class. As members of a socially stratified society, some students found themselves based on their point values relegated to the lower class despite their earnest negotiations with their classmates. In debriefing, the sociologist queried them about how their experiences in the game related to concepts such as social inequality, social stratification, and relative poverty. 
Table 1

Unit on Poverty and Homelessness

\begin{tabular}{|c|c|c|}
\hline Content & Content Course Activities & Applied English Course Activities \\
\hline $\begin{array}{l}\text { Social inequality, social stratification, } \\
\text { absolute poverty, and relative poverty }\end{array}$ & $\begin{array}{l}\text { 1. Assigned reading } \\
\text { 2. Questions to elicit images of } \\
\text { poverty } \\
\text { 3. Lecture accompanied by } \\
\text { question-and-answer session }\end{array}$ & $\begin{array}{l}\text { 1. Study guide questions } \\
\text { 2. Discuss reading and lecture } \\
\text { 3. Field student questions }\end{array}$ \\
\hline $\begin{array}{l}\text { Demographic characteristics of the } \\
\text { poor }\end{array}$ & $\begin{array}{l}\text { 4. Assigned reading } \\
\text { 5. Lecture accompanied by } \\
\text { question-and-answer session }\end{array}$ & $\begin{array}{l}\text { 4. Study guide questions } \\
\text { 5. Discuss reading and lecture } \\
\text { 6. Field student questions }\end{array}$ \\
\hline $\begin{array}{l}\text { Social and structural reasons for } \\
\text { poverty }\end{array}$ & $\begin{array}{l}\text { 6. Video on families Living on the } \\
\text { Edge (Gasciato \& Hughes, 1995) } \\
\text { 7. Lecture and class discussion }\end{array}$ & $\begin{array}{l}\text { 7. Debrief and discuss video } \\
\text { 8. Open note quiz on lecture }\end{array}$ \\
\hline $\begin{array}{l}\text { Definition of homelessness and } \\
\text { demographic characteristics of the } \\
\text { homeless }\end{array}$ & $\begin{array}{l}\text { 8. Video on homeless youth } \\
\text { Streetwise (McCall \& Ball, 1987) } \\
\text { 9. Lecture and discussion }\end{array}$ & $\begin{array}{l}\text { 9. Debrief and discuss video } \\
\text { 10. Open note quiz on lecture }\end{array}$ \\
\hline What is it like to be poor? & $\begin{array}{l}\text { 10. Game creating stratified society } \\
\text { called Starpower (Shirts, 1969) } \\
\text { 11. Poverty simulation } \\
\text { 12. Oral presentation of findings } \\
\text { from poverty simulation }\end{array}$ & $\begin{array}{l}\text { 11. Divide students into families and } \\
\text { supply information on jobs, salaries, } \\
\text { and family budgets } \\
\text { 12. Locate affordable apartment } \\
\text { from simulated newspaper } \\
\text { advertisements } \\
\text { 13. Visit grocery store and thrift shop } \\
\text { to price food and clothing } \\
\text { 14. Assist, as needed, in preparation } \\
\text { of oral presentation }\end{array}$ \\
\hline Homelessness in Japan & $\begin{array}{l}\text { 13. Assigned reading } \\
\text { 14. Debate: should the Shinjuku } \\
\text { cardboard city have been razed? }\end{array}$ & $\begin{array}{l}\text { 15. Question-and-answer session for } \\
\text { assigned reading } \\
\text { 16. Debate teams prepare } \\
\text { arguments, counterarguments, } \\
\text { rebuttals } \\
\text { 17. Review useful debate } \\
\text { expressions }\end{array}$ \\
\hline
\end{tabular}

As a second experiential exercise, students took part in a poverty simulation in which, grouped into two- to four-member families, they were assigned jobs, hourly wages, and monthly budgets. From a housing board put together by the Applied English professor, students read advertisements and selected an affordable apartment. Next, each family wrote a food and clothing shopping list that they took with them to the grocery store and thrift shop where they carefully priced their proposed purchases. Comparing the total costs of these items with their set monthly earnings, they talked, if necessary, about how to reduce family spending. Their decisions were then presented orally to their classmates as a finalized monthly budget with accompanying 
justification. Although students relied on their reading and writing skills throughout this exercise, speaking and listening were emphasized during the oral presentations.

Finally, students read about recent actions taken by public officials to displace the homeless from various locations in Japan. Applying what they had learned about poverty and homelessness in the US, they debated whether the Tokyo metropolitan government should have destroyed the cardboard houses of the homeless who were residing in the underground passages of the Shinjuku railway station. To prepare them for this exercise, the Applied English professor taught students different debate techniques and expressions for the effective presentation of their positions. After orally rehearsing their arguments, counterarguments, and rebuttals, they were ready for the debate that took place in the content course.

Taken together, these preparatory assignments were instrumental in building students' cognitive knowledge, cross-cultural understanding, and language competences. Moreover, they furnished the academic context for students' service-learning projects.

\section{Unit on Volunteerism}

Table 2 shows the content and language activities designed to educate students about volunteerism in the US through an active, problem-posing approach that combined reading, writing, speaking, and listening exercises. Based on several assigned readings, students discussed with the Applied English professor those aspects of volunteering that struck them as the most interesting. The completion of a written chronology marking significant events helped them to place volunteering in a larger historical context.

Until this point, we had been operating without a definition of volunteering. Distributing a list of 10 statements that students read before attending class, the sociologist asked them to decide if, for example, coaching a youth soccer team, establishing a university recycling program, or delivering food to a sick grandparent constituted volunteering. As they explained their opinions orally, the sociologist put their ideas on the blackboard. She then referred to the blackboard when she offered definitions of volunteering commonly cited in the professional literature.

After laying this preliminary groundwork, students working in small groups thought about and recorded in writing their images of typical volunteers in the US, namely, who they are, in addition to where, when, how, and why they volunteer. These impressions were reported orally to the entire class and then compared with the demographic characteristics of volunteers provided by the sociology professor.

Interested in learning more from the people involved on the frontlines of volunteering, we invited volunteer coordinators from the school district, the YWCA, St. Vincent de Paul, and Special Olympics to talk with students about 
Table 2

Unit on Volunteerism

\begin{tabular}{|c|c|c|}
\hline Content & Content Course Activities & Applied English Course Activities \\
\hline Definitions of volunteering & $\begin{array}{l}\text { 1. Assigned reading } \\
\text { 2. Read a statement and take a } \\
\text { position on whether it represents } \\
\text { volunteering }\end{array}$ & $\begin{array}{l}\text { 1. Identify two interesting ideas from } \\
\text { the reading } \\
\text { 2. Create chronology of volunteering } \\
\text { in the US } \\
\text { 3. Discuss other examples of } \\
\text { volunteering }\end{array}$ \\
\hline $\begin{array}{l}\text { Common characteristics of } \\
\text { volunteers }\end{array}$ & $\begin{array}{l}\text { 4. Assigned reading } \\
\text { 5. Group activity to identify students' } \\
\text { images of volunteers } \\
\text { 6. Lecture accompanied by } \\
\text { question-and-answer session }\end{array}$ & $\begin{array}{l}\text { 4. Prepare poster of images for } \\
\text { informal report } \\
\text { 5. Discuss and list reasons for } \\
\text { volunteering in the US }\end{array}$ \\
\hline $\begin{array}{l}\text { Community and personal } \\
\text { significance of volunteering }\end{array}$ & $\begin{array}{l}\text { 7. Panels of volunteer coordinators } \\
\text { and volunteers } \\
\text { 8. Reaction paragraphs }\end{array}$ & $\begin{array}{l}\text { 6. Write panelist questions } \\
\text { 7. Discuss what was learned } \\
\text { 8. Write thank-you notes }\end{array}$ \\
\hline Different ways of volunteering & $\begin{array}{l}\text { 9. Assigned reading } \\
\text { 10. Group role-play of reading about } \\
\text { volunteering }\end{array}$ & $\begin{array}{l}\text { 9. Study guide questions } \\
\text { 10. Assist students to develop ideas } \\
\text { and outline for role-play }\end{array}$ \\
\hline $\begin{array}{l}\text { Advantages and disadvantages of } \\
\text { volunteering to solve society's } \\
\text { problems }\end{array}$ & $\begin{array}{l}\text { 11. Assigned reading } \\
\text { 12. Lecture and class discussion } \\
\text { 13. Debate: is volunteering more } \\
\text { harmful than good in solving } \\
\text { society's problems? }\end{array}$ & $\begin{array}{l}\text { 11. Review typical debate } \\
\text { expressions and format } \\
\text { 12. Debate teams prepare } \\
\text { arguments and rebuttals } \\
\text { 13. Review evaluation criteria } \\
\text { 14. Discuss article for debate }\end{array}$ \\
\hline Volunteer training & $\begin{array}{l}\text { 14. Assigned reading } \\
\text { 15. Lecture and class discussion } \\
\text { 16. Volunteer orientation }\end{array}$ & $\begin{array}{l}\text { 15. Study guide questions } \\
\text { 16. Discuss volunteer qualities } \\
\text { 17. Open-notebook quiz on lecture }\end{array}$ \\
\hline Volunteer activity & $\begin{array}{l}\text { 17. Service-learning weekend } \\
\text { 18. Oral reflection of volunteer } \\
\text { experience }\end{array}$ & $\begin{array}{l}\text { 18. Planning meeting } \\
\text { 19. Discuss debriefing questions }\end{array}$ \\
\hline Definitions of volunteering & $\begin{array}{l}\text { 19. Reread statements from the } \\
\text { beginning of the unit and take a } \\
\text { position on whether they represent } \\
\text { volunteering }\end{array}$ & $\begin{array}{l}\text { 20. Group review of unit } \\
\text { 21. Discuss key unit ideas } \\
\text { 22. Formulate own definition of } \\
\text { volunteering }\end{array}$ \\
\hline $\begin{array}{l}\text { Unit integration and application of } \\
\text { content materials }\end{array}$ & $\begin{array}{l}\text { 20. Letter to friend explaining why } \\
\text { they should or should not consider } \\
\text { volunteering }\end{array}$ & $\begin{array}{l}\text { 23. Discuss another article } \\
\text { 24. Review letter assignment } \\
\text { 25. Group discussion of the letter } \\
\text { assignment and examples to support } \\
\text { answer }\end{array}$ \\
\hline
\end{tabular}

the role of volunteers in their respective organizations. Another group, composed of high school and college students, shared their personal experiences as volunteers. Before each session, American Society students prepared a list of questions that they later asked the panelists. Besides listening and speak- 
ing, they took notes of what had been said, to which they made reference in oral debriefing and in composing one-paragraph thought responses. In addition, they wrote and sent personal thank-you notes to all panel participants.

To acquaint students with the types of volunteer opportunities available in the US, the sociologist distributed short articles about tree-planting, salmon recovery, tutoring, mentoring, and home refurbishing for elderly and disabled people. One article was assigned to each of five student groups, who read it, discussed it, and scripted it into a play that they rehearsed and performed before their classmates.

Adopting a more critical stance, students considered the advantages and disadvantages of volunteering in dealing with large-scale social problems such as homelessness or domestic violence. After reading an article about whether service is part of the problem or part of the solution, the sociologist lectured about its potential dangers. Students then debated whether volunteering does more harm than good in a society after planning and rehearsing their arguments with the Applied English professor.

The time had now arrived for our service-learning weekend. A three-day training session preceded our action. On the first day, we had representatives from the different agencies where we would serve address the class about their programs. Having requested informational brochures in advance, students divided into four groups read one of these pamphlets and wrote a series of questions that they asked invited speakers after hearing a brief agency overview. In our second meeting, students orally enumerated the qualities of a good volunteer and raised questions about the planned weekend events. Their inquiries led to a discussion of how they were expected to act and how they could handle certain situations should they occur. At our last session, students matched words such as compassion, dependability, and enthusiasm for learning to related definitions as a way to reinforce the most sought-after qualities in volunteers.

Our in-class preparation had come to a close. Through different listening and speaking exercises, students had prepared and participated in class discussions, role-plays, debates, and informal and formal reports. Reading and writing skills were developed mainly through answering study guide questions aimed at helping students to identify key vocabulary and main ideas that could then be incorporated into scripting a play, composing questions for panelists, and putting together debate arguments and rebuttals. It was now time to act.

\section{Service-Learning: Action}

As the definition of service-learning makes clear, action revolves around human and community needs. Characteristic of the exploratory phase outlined in the Service Learning Model (Delve et al., 1990), I and the Applied English professor opted for one-time, short-term group activities with some 
face-to-face interaction. Thus students would be brought into contact with people and situations related to poverty and homelessness.

Over the years, we organized half-day service-learning projects that included both professors at a variety of community agencies. Seeking to lengthen the duration of our commitment, we put together a weekend of service, sometimes called an alternative weekend, as the capstone event to the units on poverty and homelessness and volunteerism. Although not ideal in terms of giving students a complete picture of different social and cultural groups, an alternative weekend does provide real-life experiences for oral and written assignments at the same time as it expands their understanding of social, economic, and urban issues (McCarthy, 1996).

Fortunately, we were able to hire a Willamette University student coordinator whose main responsibility was to plan our alternative weekend. Contacting different agencies from a list compiled by the sociologist, she inquired if they had group service projects available in which the TIUA students could participate. At weekly meetings with the sociologist, she reported on her progress in coordinating this event.

Negotiations with the community agency had to take several factors into consideration. First, the agency must be willing to work with non-native English-speaking students on a short-term basis. Second, a staff member would need to be present to give a tour of their facility so that students could learn about each organization as they communicated in English with agency representatives. Third, if possible, the agency, would arrange activities in which students would interact with clients and staff. Such direct contact had the twofold advantage of learning from and speaking with others.

After reaching agreements with the personnel from a youth drop-in center, homeless shelter, women's crisis center, and residential facility for mentally ill homeless adults, the student coordinator and sociologist put together a weekend schedule and finalized other arrangements. The student coordinator took responsibility for reserving two vans to transport the students from site to site, for borrowing rakes from the university groundskeeping office for use at the youth drop-in center and the homeless shelter, and for ordering student brown bag lunches from the university food service. Meanwhile, the sociologist purchased work gloves for raking the leaves at the drop-in center and homeless shelter, bought juice and pastry for students' breakfast on Saturday morning, and planned reflection exercises. Assembling art supplies for children at the homeless shelter and buying the ingredients for dinner at the youth drop-in center on Friday evening were tasks assigned to the Applied English professor. See Table 3 for a summary of the weekend schedule.

On Friday afternoon, students went to the drop-in home and resource center for street youth where they fixed a traditional Japanese meal. In addition to preparing food, they raked leaves, listened to music, and played 
games while they talked with the adolescents who frequented the center. Dinner proved to be the most significant moment as some youth shared stories about the struggles they faced in their lives on the streets.

Early Saturday morning, one group of students visited a residential shelter providing transitional housing for homeless families with the sociologist and student coordinator while another group went to the local women's crisis center with the Applied English professor. At the homeless shelter, students raked leaves and played football and soccer with the children living at the facility. They also spoke with some of the parents and learned that many of them were employed, yet not earning enough money to afford permanent housing. Toward lunch time, the volunteer coordinator took students on a tour of the residence, explaining its mission and method of operation. The morning ended with students and children sharing lunch and enjoying each other's company.

The other group, who had traveled to the women's crisis center, learned about domestic violence and the multitude of services available to women and children in need. In addition to the shelter, the agency had a hotline, support groups, and educational programs for the general public. After this orientation session, the students, teacher, and staff picked up litter, including needles and other drug paraphernalia, along the street where the crisis center administrative building was located.

Afterward, this group moved to the homeless shelter just as the other group was leaving for their afternoon assignment. Besides raking leaves and

Table 3

Alternative Weekend Service Schedule

\begin{tabular}{llll}
\hline Service Location & Friday Afternoon & Saturday Morning & Saturday Afternoon \\
\hline Youth Drop-In Center & $\begin{array}{l}\text { The entire class } \\
\text { accompanied by the Applied } \\
\text { English professor and the } \\
\text { student coordinator }\end{array}$ & $\begin{array}{l}\text { One half of the class } \\
\text { accompanied by the } \\
\text { sociologist and the } \\
\text { student coordinator }\end{array}$ & $\begin{array}{l}\text { The other half of the class } \\
\text { accompanied by the } \\
\text { Opplied English professor }\end{array}$ \\
Homeless Shelter & $\begin{array}{l}\text { One half of the class } \\
\text { accompanied by the } \\
\text { applied English } \\
\text { professor }\end{array}$ & \\
$\begin{array}{l}\text { Women's Crisis } \\
\text { Center }\end{array}$ & & $\begin{array}{l}\text { One half-of the class } \\
\text { accompanied by the } \\
\text { sociologist and the student } \\
\text { coordinator }\end{array}$ \\
\hline $\begin{array}{l}\text { Residential Facility for } \\
\text { Mentally III Homeless }\end{array}$ & &
\end{tabular}


playing football and soccer, these students performed a shadow puppet show that included both children and parents. Later in the day, the volunteer coordinator took this group on a tour of the facility and answered their various questions.

The other group, along with the sociologist and the student coordinator, went to a facility temporarily housing mentally ill homeless adults. Students were shown around the residential grounds and given a brief agency overview by the on-site supervisor. After addressing students' questions, she distributed cleaning supplies and escorted them to the cottage that they would clean. Sharing this task, the sociologist, student coordinator, and students had a chance to become better acquainted.

In the late afternoon, both groups gathered to process their experiences critically. Oral and written exercises provided the basis for reflection.

\section{Service-Learning: Reflection}

Preparation and action are incomplete without reflection (Jacoby, 1996), a process that encourages students to connect their firsthand experiences with course content (Chapin, 1998). Generally, oral, written, and audiovisual exercises are employed to make meaning and to move students to deeper levels of understanding. In our case, we combined oral and written activities as we endeavored to foster critical thinking among students.

Oral reflection took place on Saturday evening at the conclusion of action. Coming together in a circle, students were asked a series of questions by the sociologist, beginning with such basic inquiries as What did you do? What did you see? What did you hear? What did you say? and What did you learn and experience? From there she progressed to How did your experiences relate to what you learned in class, and What evidence did you observe of social inequality, social stratification, relative poverty, and absolute poverty? Last, she asked, "Based on your experiences, what are the social causes of poverty and homelessness? How would you propose to reduce the incidence of poverty and homelessness in the US?"

In addition to oral reflection, the sociologist prepared a written assignment that was distributed in class the following Monday. In order to personalize their experiences and make them relevant to their lives, students were asked to write a letter to a friend in which they reconsidered some of the questions previously discussed during oral reflection. For example, they had to explain to their friends what they did, what they learned, what causes poverty and homelessness, how these problems could be solved, and why their friends should or should not think about becoming involved in volunteering. In composing the letter, they were instructed to relate their firsthand experiences to course content as they argued for or against a friend's engagement in service. It was hoped that such an exercise, geared toward per- 
suasion, would give them a deeper and more critical understanding of what they had themselves so recently studied and experienced.

With the completion of the written exercise, students had progressed through the service-learning cycle of preparation, action, and reflection. Through it all, attention had been given to increasing their cognitive knowledge about poverty, homelessness, and volunteerism, exposing them to cross-cultural experiences and giving them ample and varied opportunities to practice reading, writing, speaking, and listening in English. Community involvement, albeit limited, gave students additional opportunities for growth in these three areas.

\section{Service-Learning: Faculty Evaluation}

Service-learning is much more than action. It is a comprehensive educational package that blends together preparation, action, and reflection. Any evaluation of our efforts must, therefore, be a holistic analysis of these components.

For the most part, we were pleased with our preparatory efforts. Over the past four years, we had collaborated to make substantial revisions in the content and language activities that comprised the units on poverty, homelessness, and volunteerism. In our opinion, we had developed a solid curriculum that relied on active participation and a problem-solving approach in educating students about the larger social context of poverty, homelessness, and volunteerism. By merging content and language, we consciously worked to increase their cognitive knowledge and cross-cultural understanding of the US as well as strengthen their English proficiency.

As the Applied English professor indicated, this learning framework was similar to the more familiar prereading, reading, and postreading process employed in content reading for academic courses. However, a servicelearning model boosted students' motivation, because they could apply language and content knowledge to their actions in testing whether their experiences had supported or contradicted what they had learned in the classroom. Because this approach could be characterized as highly contextualized learning through personal experience and reflection, students' passive and active vocabularies increased because of the multifaceted language activities making up preparation, action, and reflection. Service gave students a purpose and role for interacting in the community as more than observers. As a result, they gained confidence in themselves and their abilities, which was fundamental to their development of higher communication skills.

On the flip side, we were far less satisfied with our work in the areas of action and reflection. Although it was entirely reasonable to begin at the exploratory service-learning stage, we had hoped for projects that included more direct contact with people and more opportunities to use English in an authentic context. For both faculty and students, our work at the homeless 
shelter for families proved to be the most gratifying and most relevant to achieving our content, cross-cultural, and language-learning goals. We hope to plan a future alternative weekend consisting of more interpersonal activities at different locations in the community.

Another consideration was the time and duration of service. In addition to Friday and Saturday, we would like to extend our activities to Sunday. Conceivably, we could spend a full day at one community agency on Saturday and at another on Sunday, thus giving us deeper and richer learning experiences at each site.

Reflection was also problematic. Although our planned exercises allowed students to speak and write in English, they were not sufficiently challenged to confront their earier assumptions and wrestle with what they had learned. Alternative assignments such as oral reflection with agency representatives, written policy statements on reducing the incidence of poverty, journal entries shared with peers, and discussions connecting additional readings with students' experiences are possible. As such, reflection needs to be given more careful thought.

\section{Conclusion}

Understandably, some educators may be highly critical of and troubled by our approach to service-learning. Indeed, exploratory projects may maintain a hierarchical relationship between server and served that further victimizes the disadvantaged. Because a reciprocal relationship may not be established, the servers may end up doing for rather than doing with the served.

Obviously, this was an ever-present danger in the kinds of activities described here. We were in direct contact for only a fleeting moment with people who are poor and homeless. Such limited interaction threatened to reinforce, rather than call into question, existing stereotypes and preconceptions. Thus the questions that need to be addressed are: how can short-term activities be performed in a manner that is not patronizing or disrespectful, and how can they be carried out in a way that promotes content, cross-cultural, and language-learning?

Admittedly, the alternative weekend represents only one of many types of service-learning projects. As the instructors, we prefer this approach, because by being part of the action we can model respectful relationships with others in which we have as much to learn from homeless families, for example, as they do from us. In addition, the preparatory and volunteer training phases of service-learning are intended to educate students before they serve and to challenge some of their preexisting notions. We hope such efforts make students more accepting and less judgmental about other people's situations.

Reflection also helps to uncover certain prejudices and biases by having students voice what they think, feel, and experience. Analyzing their re- 
sponses can foster new understanding, thereby leading to the growth of cognitive knowledge and cross-cultural awareness.

Our ultimate success is dependent on communicating what has been learned and experienced through reading, writing, speaking, and listening in English both inside and outside the classroom. Service-learning provides rich opportunities to practice language. Furthermore, contact with different cultural groups, whether disadvantaged or not, may motivate students to bridge the communication gap between them by becoming more proficient in English. As a result, service-learning holds great promise for increasing language proficiency.

In the end, educators must take great care in designing service-learning activities. Although content, cross-cultural, and language-learning may be our major objectives, they must not be achieved at the expense of harming other people. Therefore, assessing the impact of these efforts on the individuals being served, as well as measuring what students are and are not learning, are the important next steps in incorporating service-learning in ESL programs around the world.

\section{Acknowledgment}

The author wishes to thank J. Sirena Tabet, who teaches the linked Applied English course, for her advice and support in preparing this article.

\section{The Author}

Linda Heuser is an Associate Professor of Sociology at Willamette University in Salem, Oregon. For the past seven years she has taught sheltered-content courses to Japanese students who are studying in the US. She is interested in developing effective pedagogical techniques to enhance their educational experiences.

\section{References}

Beebe, R.M., \& DeCosta, E.M. (1993). The Santa Clara University Eastside Project community service and the Spanish classroom. Hispania, 76, 884-891.

Beckman, M. (1997). Learning in action: Courses that complement community service. College Teaching, 45, 72-75.

Brandell, M.E., Hitch, E., Kromer, T., \& Misner, J.C. (1994). Learning through service: Enriching the classroom experience. Delta Kappa Gamma Bulletin, 60, 11-16.

Burkholder, J.L. (1989). The idea of service in international education. In S.W. Showalter (Ed.), The role of service-learning in international education (pp. 25-33). Goshen, IN: Goshen College.

Chapin, J.R. (1998). Is service learning a good idea? Data from the national longitudinal study of 1988. Social Studies, 89, 205-211.

Ciaccio, J., \& Walker, G.C. (1998). Nursing and service learning: The Kobyashi Maru. Nursing and Health Care Perspectizes, 19, 175-177.

Crabtree, R.D. (1998). Mutual empowerment in cross-cultural participatory development and service learning: Lessons in communication and social justice from projects in El Salvador and Nicaragua. Journal of Applied Communication Research, 26, 182-209.

Crandall, J., Spanos, G., Christian, D., Simich-Dudgeon, \& Willetts, K. (1987). Integrating language and content instruction for language minority students. Wheaton, MD: National Clearinghouse for Bilingual Education. 
de la Luz Reyes, M., \& Molner, L.A. (1991). Instructional strategies for second-language learners in the content areas. Journal of Reading, 35, 96-103.

Delve, C.I., Mintz, S.D., \& Stewart, G.M. (1990). Promoting values development through community service: A design. In C.I. Delve, S.D. Mintz, \& G.M. Stewart (Eds.), New directions for student services, no. 50 (pp. 7-29). San Francisco, CA: Jossey-Bass.

Dollar, B., \& Rust, V. (1983). Learning by participation. In H. Chisnall (Ed.), Learning from work and community experience: Six international models (pp. 5-47). London: NFER-Nelson.

Eberly, D.J. (1997). An international perspective on service-learning. In J. Schine (Ed.), Service learning. Ninety-sixth yearbook of the National Society for the Study of Education (part 1, pp. 19-31). Chicago, IL: University of Chicago Press.

Friere, P. (1970). Pedagogy of the oppressed. New York: Seabury Press.

Gasciato, T., \& Hughes, K. (1995). Living on the edge [Film]. (Available from Public Broadcasting Service, Alexandria, VA)

Giroux, H.A. (1993). Living dangerously: Multiculturalism and the politics of difference. New York: Lang.

Giroux, H.A. (1997). Pedagogy and the politics of hope: Theory, culture, and schooling: A critical reader. Boulder, CO: Westview Press.

Hatcher, J.A., \& Bringle, R.G. (1997). Reflection: Bridging the gap between service and learning. College Teaching, 45, 153-158.

Hayes, S.A. (1996). Cross-cultural learning in elementary guidance activities. Elementary School Guidance and Counseling, 30, 264-274.

hooks, b. (1994). Teaching to transgress: Education as the practice of freedom. New York: Routledge.

Jacoby, B. (1996). Service-learning in today's higher education. In B. Jacoby \& Associates (Eds.), Service-learning in higher education (pp. 3-25). San Francisco, CA: Jossey-Bass.

Jeavons, T. (1989). Connecting the curriculum and the community. Liberal Education, 75, 20-25.

Kelleher, A., \& O'Brien, J.M. (1991). Surveying AAC members: Planning for global and international education. Liberal Education, 77, 30-43.

Kendall, J.C. (1990). Combining service and learning: An introduction. In J.C. Kendall (Ed.), Combining service and learning: A resource book for community and public service (vol. 1, pp. 1-33). Raleigh, NC: National Society for Experiential Education.

Kendall, J.C. (1991). Combining service and learning: An introduction for cooperative education professionals. Journal of Cooperative Education, 27, 9-26.

King, A. (1993). From sage on the stage to guide on the side. College Teaching, 41, 30-35.

Kraft, R.J. (1996). Service learning: An introduction to its theory, practice, and effects. Education and Urban Society, 28, 131-159.

Kwapong, A.A. (1989). Some reflections on the role of international education in the '90s. In S.W. Showalter (Ed.), The role of service-learning in international education (pp. 15-24). Goshen, IN: Goshen College.

Leistyna, P. (1999). Presence of mind: Education and the politics of deception. Boulder, CO: Westview Press.

McCall, C. (Producer), \& Ball, M. (Director). (1987). Streetwise [Film]. (Available from Angelika Films, New York)

McCarthy, M.D. (1996). One-time and short-term service-learning experiences. In B. Jacoby \& Associates (Eds.), Service-learning in higher education (pp. 113-134). San Francisco, CA: Jossey-Bass.

Mintz, S.D., \& Hesser, G.W. (1996). Principles of good practice in service-learning. In B. Jacoby \& Associates (Eds.), Service-learning in higher education (pp. 26-52). San Francisco, CA: Jossey-Bass.

Morgan, B.D. (1998). The ESL classroom: Teaching, critical practice, and community development. Toronto, ON: University of Toronto Press. 
Ochoa, A. (1996). Introduction. Constructively moving forward: Creative educators, creative learners. In W. Enloe with D. Willis, K. Evans, J. Gasperini, \& colleagues (Eds.), Creating context: Experiencing and understanding cultural zorlds (pp. 1-3). Tucson, AZ: Zephyr Press.

Parker-Gwin, R., \& Mabry, J.B. (1998). Service learning as pedagogy and civic education: Comparing outcomes for three models. Teaching Sociology, 26, 276-291.

Rasmussen, J.E. (1991). Consummating the union: Language and international studies as compatible means. Liberal Education, 77, 8-13.

Rice, K. (1996). Strengthening service-learning through faculty and student affairs partnerships. In M.G. Ender, B.M. Kowalewski, D.A. Cotter, L. Martin, \& J. DeFiore (Eds.), Service-learning and undergraduate sociology: Syllabi and instructional materials (pp. 14-20). Washington, DC: American Sociological Association.

Shirts, R.G. (1969). Starpower. La Jolla, CA: Western Behavioral Sciences Institute.

Shor, I. (1992). Empowering education: Critical teaching for social change. Chicago, IL: University of Chicago Press.

Shor, I. (1996). When students have power: Negotiating authority in a critical pedagogy. Chicago, IL: University of Chicago Press.

Snow, M.A., Met, M., \& Genesee, F. (1989). A conceptual framework for the integration of language and content in second/foreign language instruction. TESOL Quarterly, 23, 201-217.

Thullen, M. (1989). International education at Michigan State University. In S.W. Showalter (Ed.), The role of service-learning in international education (pp. 69-81). Goshen, IN: Goshen College.

Ward, J.V. (1997). Encouraging cultural competence in service learning practice. In J. Schine (Ed.), Service learning. Ninety-sixth yearbook of the National Society for the Study of Education (part 1, pp. 136-148). Chicago, IL: University of Chicago Press.

Weaver, H.D., Kauffmann, N., \& Martin, J. (1989). Educational value of international experience. In S.W. Showalter (Ed.), The role of service-learning in international education (pp. 59-68). Goshen, IN: Goshen College.

Yoder, D.I., Retish, E., \& Wade, R. (1996). Service learning: Meeting student and community needs. Teaching Exceptional Children, 28, 14-18. 